\title{
Surface analysis of doped lanthanide cobalt perovskites by X-ray photoelectron spectroscopy
}

\author{
V. KOZHUKHAROV, M. MACHKOVA \\ University of Chemical Technology and Metallurgy, 1756 Sofia, Bulgaria \\ P. IVANOV \\ Laboratory for Surface Analysis, DZU-DMON, Stara Zagora 6009, Bulgaria
}

H. J. M. BOUWMEESTER, R. VAN DOORN

Laboratory for Inorganic Materials Science, Faculty of Chemical Technology, University of Twente, 7500 AE Enschede, The Netherlands

High oxygen fluxes through mixed-conducting oxides with fluoride and perovskite structure are well known [1-3]. According to [4] the selective feeding of oxygen into high temperature electrochemical reactors generally comprises: (i) providing an electrochemical cell comprising a first zone and a second zone separated from the first by a solid multicomponent membrane; (ii) raising the temperature of the electrochemical cell from about $300^{\circ} \mathrm{C}$ to about $1400^{\circ} \mathrm{C}$; (iii) passing the oxygen-containing gas in surface contact with the membrance, and (iv) passing the methane in contact with the membrane surface in the second zone.

It is evident that under a high temperature working regime, the permeability of oxygen, as well as all of the other physical and chemical parameters, are very important for the realization of a highly effective chemical process at a large oxygen partial pressure gradient. The catalytic activity of such an oxidation process, e.g. of $\mathrm{CO}$, methane, etc., is a function of the chemical state of the surface elements and decreases monotonically with the decrease of the surface atomic ratio of the 3-rd elements.

In the work reported here the chemical state of the surface of an Sr-doped lanthanide cobalt perovskite $\left(\mathrm{La}_{0.3} \mathrm{Sr}_{0.7} \mathrm{CoO}_{3-\delta}, 3 \mathrm{LSC}\right)$ was the object of an investigation carried out with the help of electron spectroscopy for chemical analysis (ESCA), including the X-ray photoelectron spectroscopy (XPS) and Auger electron spectroscopy (AES) methods.

In our work the method of preparation of perovskite ceramic samples developed by van Doorn and Bouwmeester [5] was accepted. The materials used were $\mathrm{La}\left(\mathrm{NO}_{3}\right)_{3} \cdot 6 \mathrm{H}_{2} \mathrm{O}, \mathrm{Co}\left(\mathrm{NO}_{3}\right)_{3} \cdot 6 \mathrm{H}_{2} \mathrm{O}$ and $\mathrm{Sr}\left(\mathrm{NO}_{3}\right)_{2}$ of Analar grade from Merck. According to the concept of preparation of perovskite ceramics, $\mathrm{NH}_{4}-$ EDTA solution was added to clear nitrate solutions, containing stoichiometric amounts of reagents. All other technological steps were in accordance with the route given in [5]. AES and XPS surface testing was accomplished by Microlab VG Scientific equipment with an $\mathrm{Al}_{\alpha}$ source $(1486.0 \mathrm{eV})$ for a binding energy $(\mathrm{BE})$ region above $20 \mathrm{eV}$ and below $20 \mathrm{eV}$ with an $\mathrm{Mg} K_{\alpha}(1253.6 \mathrm{eV})$ $\mathrm{X}$-ray source. The survey spectra were determined at
$450{ }^{\circ} \mathrm{C}$ for $30 \mathrm{~min}$, rejecting the $\mathrm{OH}^{-}$surface absorption units.

Fig. 1 shows the XPS valence band spectrum of a 3LSC sample and the O2s peak position at $21.5 \mathrm{eV}$. Following the experiment, Fig. 2 presents a survey XPS spectrum observed up to $1350 \mathrm{eV}$ of the BE values. XPS and Auger lines excited by X-rays of the elements $\mathrm{Co}, \mathrm{Sr}, \mathrm{La}, \mathrm{C}$ and $\mathrm{O}$ can be seen clearly. The C1s line always appears in the XPS spectra. We admit that this is contributed by two carbon sources, firstly from the influence of the diffusion pump, and secondly, from the organic component (EDTA) in the course of the synthesis. An extended spectra of region (a) is also presented in Fig. 2.

Since the XPS valence band spectra were not well resolved, we would like to point out only that, from the photoemission behaviour, the peak with the high $\mathrm{BE}$ close to $5-6 \mathrm{eV}$ (marked by the arrow in Fig. 1) arises from the states with primary $\mathrm{O} 2 \mathrm{p}$ character. It is known that at $3 \mathrm{~d}$ elements metal-derived $3 \mathrm{e}_{\mathrm{g}}$ and

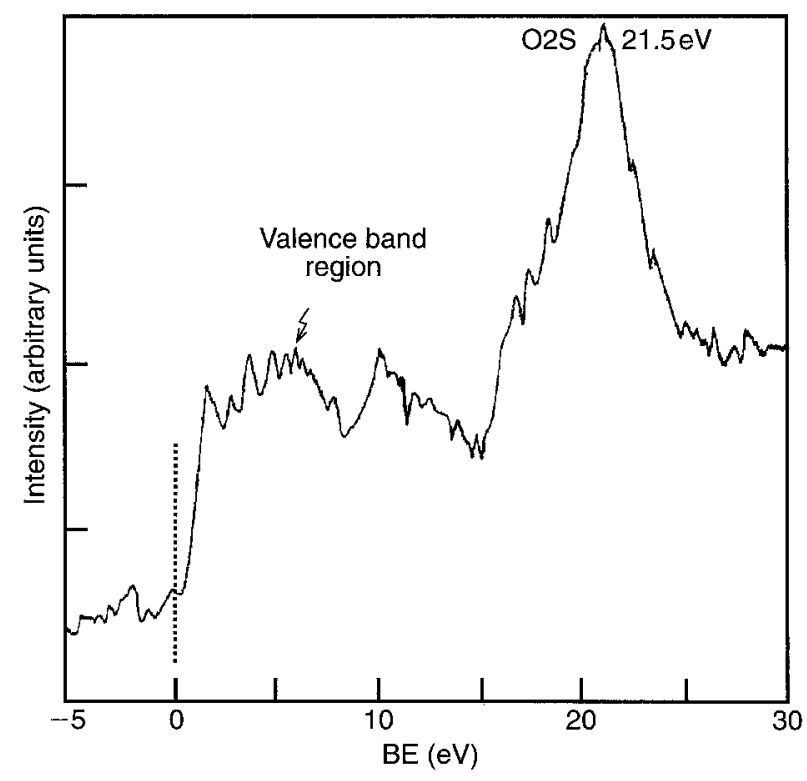

Figure I The XPS spectrum from -5 to $30.0 \mathrm{cV}$ binding energy, $\mathrm{Mg} K_{\alpha} \mathrm{X}$-ray source, analyser energy $10 \mathrm{eV}$ and step size $0.20 \mathrm{eV}$. The zero of the binding scale correlates to the Fermi level. 


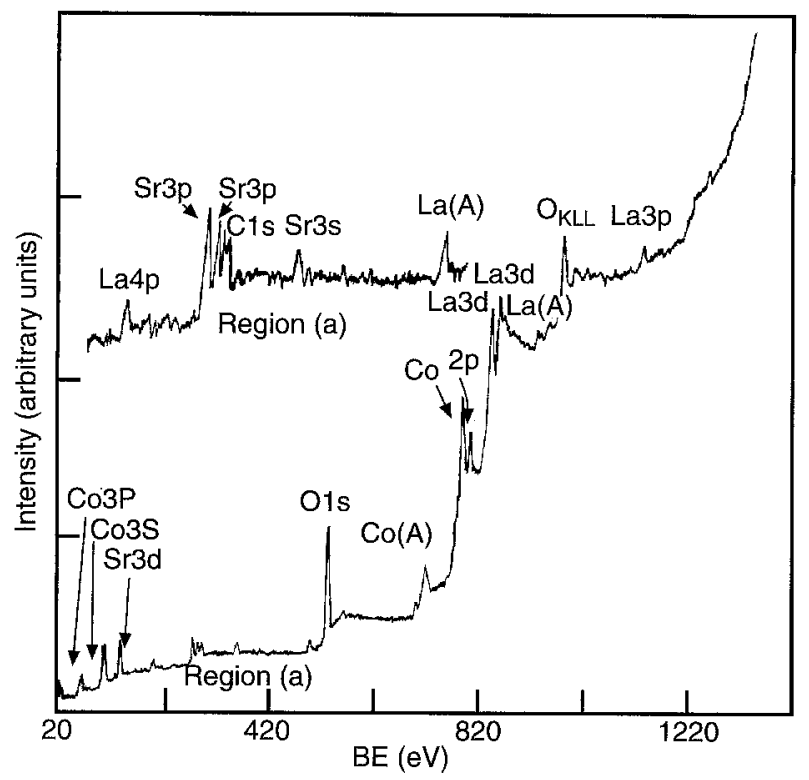

Figure 2 Survey spectrum from 20 to $1350 \mathrm{eV}$ of $3 \mathrm{LSC}$ sample at $\mathrm{Al} K_{\alpha}$ source, analyser energy $50 \mathrm{eV}$ and step size $1.0 \mathrm{eV}$.

$2 \mathrm{t}_{\mathrm{g}}$ levels appear in the $2 \mathrm{p}$ hybridization mechanism of oxygen.

The detailed spectrum, including La3d, La4p and LaMNN Auger lines, is shown in Fig. 3. It is evident that the peaks are complex and, along with the main peak, there are shoulders on both sides at the La $(195 \mathrm{eV})$ line. This is probably due to the different coordination states of the La atoms, irrespective of the high value of the dissociation energy, which is shifted in the order from $\mathrm{LaO}\left(D_{\mathrm{o}}=801 \mathrm{~kJ} \mathrm{~mol}^{-1}\right)$ to $\mathrm{SrO}\left(D_{\mathrm{o}}=527 \mathrm{~kJ} \mathrm{~mol}^{-1}\right)$ to $\mathrm{CoO} \quad\left(D_{\mathrm{o}}=\right.$ $\left.361 \mathrm{~kJ} \mathrm{~mol}^{-1}\right)$ [6].

The XPS spectra of Sr3p and Sr3d are presented in Fig. 4. Undoubtedly, the spectra manifest the presence of the different valence states of Sr. The $\mathrm{BE}$ of the main peak at $133 \mathrm{eV}$ is a contribution of $\mathrm{SrO}$ with $132.6 \mathrm{eV}$. Beside this peak, there are some more shoulders, which, according to Tabata and Kohiki [7], can be assigned as $\mathrm{SrO}$ at $134.5 \mathrm{eV}$, and the peak with low $\mathrm{BE}$ value $(132.2 \mathrm{eV})$ may be due to the presence of a low oxidation state, such as $\mathrm{SrO}_{1-\delta}$ suboxide on the surface.

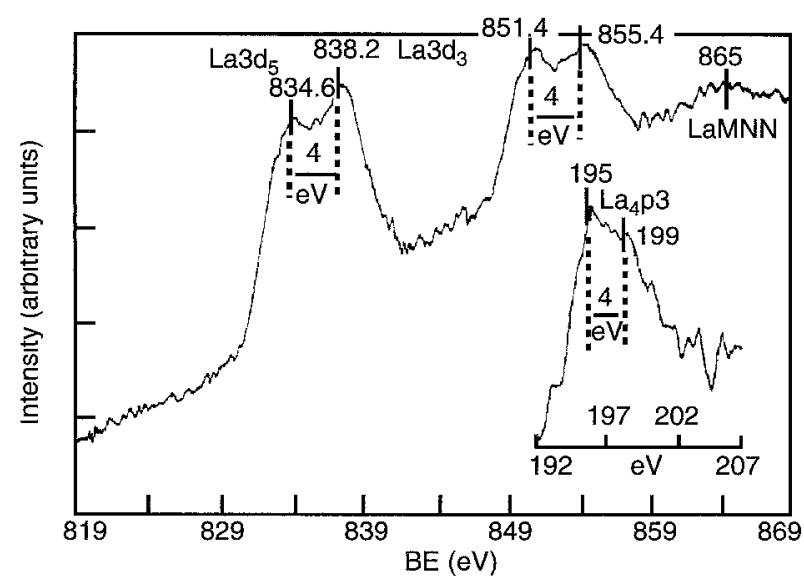

Figure 3 XPS detail spectra of the La state in LSC sample.

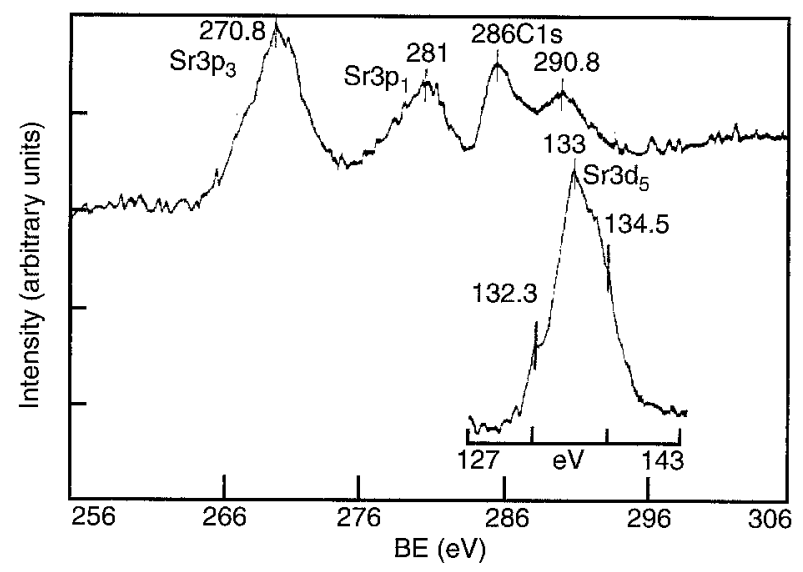

Figure 4 XPS detail spectra of the Sr contribution.

XPS spectra of cobalt contribution are presented in Fig. 5. As a good correlation at high BE values, the peak positions of $\mathrm{Co} 2 \mathrm{p}$ for 781 and $796 \mathrm{eV}$ are shown. As is discussed in [7], the BEs for $\mathrm{Co}$ (III) in $\mathrm{LC}$ perovskites is $7779.6 \mathrm{eV}$ and for $\mathrm{Co}$ (II) in $\mathrm{CoO}$ is $780.3 \mathrm{eV}$. It may be accepted that on the 3LSC surface, the part of the Co content is reduced, according to the detection of the Co2p peak position. This is a logical consequence following the low dissociation energy of the $\mathrm{CoO}$ and the high reduction ability during the calcination process.

Fig. 6 shows the spectra of O1s. It can be seen from the figure that there are three oxygen atomic states. According to [8] there are three oxygen atomic states existing in the $1: 2: 3$ perovskite families (see Fig. 6a), namely bridging oxygen ions $\mathrm{O}^{2-}$, half-bridging $\mathrm{O}^{-}$and formation of peroxide anions $\left(\mathrm{O}_{2}\right)^{2-}$ pairs. The assumption is that the O1s BE of the dimer ions lies between that of the bridging and non-bridging oxygen ions. According to the results above, any formation of peroxide (O-O dimers) ions could not be accepted. There is a process of high surface reduction during the calcination or a process of non-stoichiometric oxidation during the thermal decomposition using the powder calcination process. In this context, a high amount of non-bridging $(532.2 \mathrm{eV})$ oxygen atoms is present in the 3LSC sample and co-exists with bridging $(533.6 \mathrm{eV})$

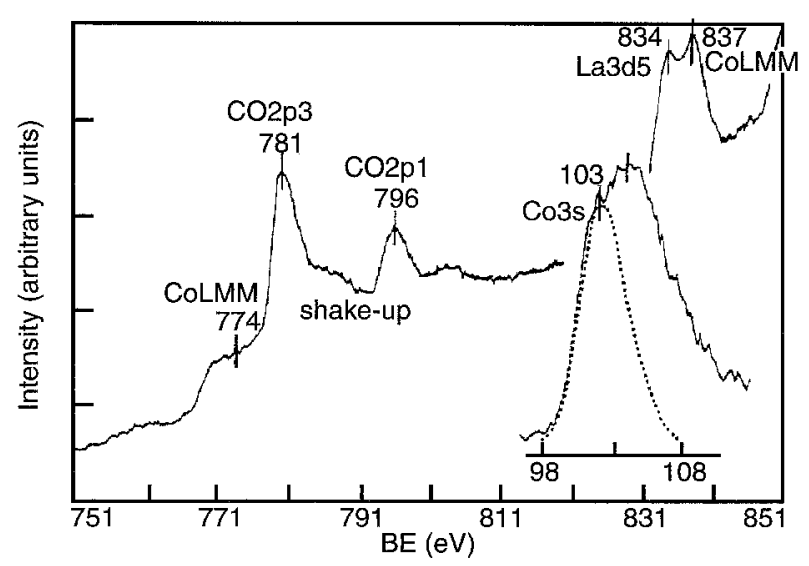

Figure 5 XPS detail spectra of $\mathrm{Co} 3 \mathrm{~s}, \mathrm{Co} 2 \mathrm{p}$ and $\mathrm{Co}_{\mathrm{LMM}}$ Auger peaks. 
TABLE I XPS data of the O1s partial distribution

\begin{tabular}{|c|c|c|c|c|c|}
\hline Number & $\begin{array}{l}\text { Peak } \\
\text { centre } \\
(\mathrm{eV})\end{array}$ & $\begin{array}{l}\text { Peak } \\
\text { width } \\
(\mathrm{eV})\end{array}$ & $\begin{array}{l}\text { Peak } \\
\text { height } \\
\text { (counts) }\end{array}$ & $\begin{array}{l}\text { Area } \\
\left(\mathrm{eV} \mathrm{ms}^{-1}\right)\end{array}$ & Contribution $^{\mathrm{a}}$ \\
\hline 1 & 529.8 & 1.80 & 7168 & 36.525 & 3d-oxygen, $\mathrm{Co}_{\mathrm{ox}}, \mathrm{La}_{2} \mathrm{O}_{3}$ \\
\hline 2 & 532.2 & 1.80 & 5144 & 28.352 & Non-bridging $\mathrm{O}^{-}, \mathrm{SrO}$ \\
\hline 3 & 533.6 & 1.80 & 4608 & 18.062 & Bridging $\mathrm{O}, \mathrm{OH}^{-}$influence \\
\hline
\end{tabular}

${ }^{\mathrm{a}} \mathrm{Co}_{\mathrm{ox}}$, Co oxidized metal surface from exposure to oxygen.

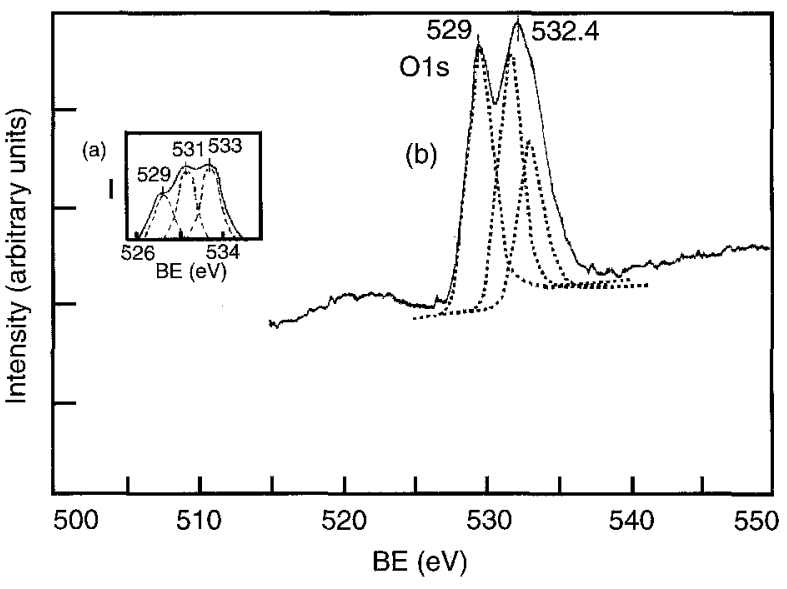

Figure 6 Oxygen partial distribution at O1s peak: (a) according to [8] and $(b)$ according to the present work; see the data in Table I.

oxygen atoms. The last peak is a contribution from the oxygen in $\mathrm{OH}^{-}$units [9] too. Following the data in Table I, the peak with the high surface area is at $529.8 \mathrm{eV}$. This amount from the total oxygen content in the sample could be associated with oxygen eventually at $\mathrm{La}_{2} \mathrm{O}_{2}$ [10] and $\mathrm{Co}_{\mathrm{ox}}(529.7 \mathrm{eV})$ [9] building. This indicates the high surface reduction contribution on the XPS spectra. As is shown in [10], this is a typical behaviour of oxygen surrouned by $3 \mathrm{~d}$ transition elements: $\mathrm{TiO}_{2}(529.7 \mathrm{eV}), \mathrm{V}_{2} \mathrm{O}_{5}$ $(530.0 \mathrm{eV}), \mathrm{Cr}_{2} \mathrm{O}_{3}(529.8 \mathrm{eV}), \mathrm{MnO}_{2}(529.8 \mathrm{eV})$, $\begin{array}{llll}\mathrm{Fe}_{2} \mathrm{O}_{3} & (529.9 \mathrm{eV}), \quad \mathrm{Co}_{3} \mathrm{O}_{4} \quad(530.0 \mathrm{eV}), \quad \mathrm{NiO}\end{array}$ $(529.6 \mathrm{eV})$ and $\mathrm{Ni}_{\text {ox }}(529.9 \mathrm{eV})$ states.

We conclude that there is a reduction process during the calcination treatment of the powder sample. This stimulates an increase of the surface non-stoichiometry, which is important for the high temperature surface oxygen exchange and for the selectivity of the catalytic reactions taking place on the surface.

\section{Acknowledgement}

The support of the Commission of the European Communities in the frame of the JOULE II program is greatly acknowledged.

\section{References}

1. A. J. BURGGRAAF, M. J. M. BOUWMEESTER, B. BOUKAMP, R. L. UHLHORN and V. ZASPALIS, in "Science of ceramic interfaces", edited by J. Nowotny (Elsevier, Amsterdam, 1991) p. 523.

2. H. J. M. BOUWMEESTER, H. KRUIDHOF and A. J. BURGGRAAF, Solid St. Ionics 72 (1994) 185.

3. Y. TERAOKA, H. M. ZHANG, K. OKAMOTO and N. YAMAZOE, Mater. Res. Bull. 23 (1988) 51.

4. EP Patent 0399833 (1990). .

5. R. H. E. VAN DOORN and H. J. M. BOUWMEESTER, private communication, July (1994).

6. A. EFIMOV, "Svoistva neorganicheskikh soedineniya", (Khimia, Leningrad, 1983) p. 57 (in Russian).

7. K. TABATA and S. KOHIKI, J. Mater. Sci. Lett. 6 (1987) 1030.

8. J. SESTAK, J. KAMARAN, P. HOLBA, A. TRISKA, E. POLLERT and M. NEVRIVA, Thermochim. Acta $\mathbf{1 7 4}$ (1991) 99

9. C. WAGNer, D. ZATKO and R. Rainold, Anal. Chem. 52 (1980) 1445.

10. V. NEFEDOV, "Rentgenoelectronaya spectroskopiya khimicheskich soedinenii" (Khimiya, Leningrad, 1984) p. 150 (in Russian).

Received 8 December 1995 and accepted 17 June 1996 